\title{
Studi Kelayakan Air Sumur Bor di Area STIPER Kutai Timur Sebagai Media Budidaya Panaeus monodon pada Kolam Terpal
}

\author{
Rudiyanto $^{1^{*}}$, Anshar Haryasakti ${ }^{2}$, dan Rosdianto ${ }^{3}$ \\ ${ }^{1,2,3}$ Sekolah Tinggi Pertanian Kutai Timur Jl. Soekarno Hatta No.1. Sangatta \\ Kabupaten Kutai Timur, Kalimantan Timur \\ 1 Email: ryantstiper@gmail.com
}

*Penulis korespondesi: ryantstiper@gmail.com

Submit: 13-10-2021

Revisi: 23-11-2021

Diterima: 8-12-2021

\begin{abstract}
Failure to harvest of East Kutai pond farmers, due to large amount of organic waste that accumulates in pond soil and affects water quality, utilization of tarpaulin ponds can solve the problem, there are bore-well with a salinity range of 15-20 ppm in STIPER campus area. Research aimed was to testing the feasibility of bore well water in STIPER Kutai Timur campus area as a aquaculture media for tiger prawn (Paneus monodon sp) by a tarpaulin pond system. This research was conducted on August-October 2020 in STIPER Kutai Timur Field Laboratory. Observations results of water quality obtained during the research were a salinity average range 15-20 ppt, $p H$ 7.1-8.2, temperature $26.60-29.68^{\circ} \mathrm{C}$ and DO 4.2-6.2 $\mathrm{mg} / \mathrm{l}$, the average value of water quality range as a test indicator is still within the tolerance for tiger prawn (Panaeus monodon sp). The survival rate (SR) obtained during the research was only 10\%, the low SR obtained in this research due to frequently blackouts occur which resulting in blower not functioning so that oxygen decline rapidly and resulting in death of aquaculture biota.
\end{abstract}

Keywords: DO, pH, Pond Farmers, Salinity, Temperature, Water Wuality

\section{ABSTRAK}

Kegagalan panen petani tambak Kutai Timur karena banyaknya limbah organik yang terakumulasi dalam tanah tambak dan mempengaruhi kualitas air, maka penggunaan kolam terpal dapat mengurai persoalan tersebut, dalam area kampus STIPER terdapat sumur bor ppm. Penelitian ini bertujuan untuk menguji kelayakan air sumur bor di area kampus STIPER Kutai Timur sebagai media budidaya udang windu (Panaeus monodon) dengan sistem kolam terpal. Penelitian ini dilaksanakan pada bulan Agustus-Oktober 2020 di Laboratorium Lapangan STIPER Kutai Timur. Hasil pengamatan kualitas air yang diperoleh selama penelitian berada pada ratarata kisaran salinitas $15-20$ ppm, pH 7,1-8,2, suhu $26,60-29,68^{\circ} \mathrm{C}$ dan $\mathrm{DO} 4,2-6,2$ $\mathrm{mg} / \mathrm{l}$, nilai rata-rata kisaran kualitas air tersebut masih berada dalam toleransi Udang Windu (Panaeus monodon $s p$ ) sebagai indikator uji. Tingkat kelangsungan hidup (SR) yang diperoleh selama penelitian hanya sebesar $10 \%$, rendahnya SR yang diperoleh pada penelitian ini karena seringnya terjadi pemadaman listrik yang mengakibatkan blower tidak berfungsi sehingga oksigen turun secara derastis dan beribas pada kematian pada biota budidaya.

Kata kunci: DO, Kualitas Air, pH, Salinitas, Suhu, Tambak

\section{Pendahuluan}

Perikanan menjadi faktor yang cukup penting dalam pembangunan nasional. Indonesia pernah tercatat sebagai negara penghasil udang terbesar ketiga di dunia, namun produksinya terus menurun sampai sekarang untuk mengoptimalkan perikanan budidaya. Pada awal tahun 1980-an, pemerintah telah melakukan pengembangan budidaya 
perikanan, khususnya udang dengan fasilitas berupa tambak udang windu (Penaeus monodon) dan udang putih (Penaeus merguiensis) (Athirah et al., 2014).

Kabupaten Kutai Timur merupakan salah satu kabupaten di Kalimantan Timur yang mempunyai kawasan pertambakan yang cukup luas, yang tersebar pada tujuh kecamatan pesisir dengan garis pantai sepanjang $152 \mathrm{~km}^{2}$ (Badan Pusat Statistik Kabupaten Kutai Timur, 2018), namun sampai saat ini belum ada pembudidaya yang memiliki pengetahuan dalam mengatasi permasalahan ketika proses budidaya berlangsung. Kegagalan panen rata-rata dialami oleh petani tambak di daerah Kutai Timur adalah banyaknya limbah organik yang terakumulasi dalam tambak yang nantinya mempengaruhi kualitas air, terdapatnya mikroorganisme (bakteri) aerob yang terdapat di sedimen/tanah tambak (Rudiyanto, 2014). Kegagalan panen bagi para pembudidaya, dapat terjadi akibat proses fisika, kimia dan biologi dalam tanah yang berdampak pada kualitas air tambak. Tanah dasar tambak merupakan salah satu faktor penting untuk menentukan pengelolaan tambak khususnya budidaya udang, sebab tanah dasar tambak berfungsi sebagai filter biologis melalui absorbsi sisa pakan, ekskreta kultivan dan metabolit alga sekaligus sebagai buffer dan penyedia hara dalam tambak budidaya (Hendrajat et al., 2018).

Sumur bor adalah salah satu proses penggalian tanah yang dilakukan agar bisa mendapatkan sumber mata air yang berada di dalam tanah dengan cara pengeboran lapisan air tanah yang lebih dalam, sehingga air yang diperoleh tidak terkontaminasi dengan air lain. Dasanto et al., (2020), mengatakan bahwa air yang mengandung kadar garam dapat diperoleh pada kedalaman kurang dari 100 meter, pada umumnya air dengan salinitas yang tinggi dapat ditemukan pada kedalaman 65-100 meter tergantung dari jarak sumur bor dan bibir pantai. Semakin dekat sumur bor dan bibir pantai maka kedalaman sumur akan lebih rendah untuk mendapatkan air bersalinitas tinggi.

Dalam area kampus STIPER terdapat sumber air sumur bor yang tujuan awalnya sebagai sumber air bersih untuk keperluan aktivitas kampus, akan tetapi sumber air tersebut memiliki salinitas berkisar $15-20$ ppm, maka sumber air tersebut tidak terpakai sampai saat ini. Menurut Syukri \& Ilham (2016) dalam penelitiannya bahwa tingkat kelulushidupan dan pertumbuhan post larva udang windu (Penaeus monodon) sangat baik pada tingkat salinitas 25 ppt dan 30 ppt, dan dipertegas oleh Erawan et al., (2021) dengan mengatakan bahwa pada tambak ekstensif pemeliharaan udang windu berada kisaran salinitas air 5-40 ppt, dan pada tambak intensif sebaiknya salinitas berada pada kisaran 2632 ppt. Tujuan penelitian ini untuk menguji kelayakan air sumur bor di area kampus STIPER Kutai Timur, sebagai media budidaya udang windu (Penaeus monodon) dengan sistem kolam terpal. 


\section{Metode Penelitian}

Penelitian ini telah dilaksanakan pada bulan Agustus sampai dengan Oktober 2020, di Laboratorium Lapangan Program Studi Budidaya Perairan Sekolah Tinggi Pertanian (STIPER) Kutai Timur, Sangatta. Untuk kegiatan ini uji kualitas air untuk mengetahui kelayakan air sumur bor yang terdapat di area kampus STIPER Kutai Timur untuk dipergunakan sebagai media budidaya udang windu (Panaeus monodon) pada kolam terpal..

Fasilitas yang digunakan pada penelitian ini adalah 2 unit kolam terpal yang dirangkai menjadi satu dan dilengkapi dengan aerator, mesin Venturi, selang dan batu aerasi dan serta pipa. Alat ukur kualitas air terdiri atas hand refractometer, thermometer, $\mathrm{pH}$ meter, DO meter, dan alat pendukung lainya seperti mesin pompa air, seser baskom dan timbangan. Bahan penelitian yang digunakan antara lain udang windu (Panaeus monodon), pakan udang, probiotik, air sumur bor, kaporit dan tiosulfat.

Pengamatan kualitas air selama penelitian dilakukan empat kali dalam sehari, yaitu pagi pada pukul 06.00 WITA, siang pukul 11.00 WITA, sore pukul 16.00 WITA dan malam pukul 22.00 WITA. Pengamatan tersebut dilakukan setiap tiga kali dalam seminggu. Kualitas air yang diukur dalam penelitian meliputi suhu, salinitas, $\mathrm{DO}$ dan $\mathrm{pH}$ air

Untuk mengetahui layak tidaknya penggunaan air sumur bor yang di jadikan sebagai media penelitian maka data yang perlu dianalisa adalah tingkat kelulushidupan indikator hewan uji. Pengukuran tingkat kelulushidupan dilakukan dengan menghitung jumlah penebaran pada awal penebaran dan jumlah yang hidup ketika panen di akhir masa pemeliharaan. Menurut Haliman \& Adijaya (2006), rumus untuk menghitung tingkat kelulushidupan (SR) adalah sebagai berikut:

$$
S R=\frac{N t}{N o} \times 100 \%
$$

Keterangan: $S R=$ Survival Rate $(\%)$

$$
\begin{aligned}
& \mathrm{Nt}=\text { Jumlah udang hidup pada akhir pemeliharaan (ekor) } \\
& \mathrm{No}=\text { Jumlah udang pada awal pemeliharaan (ekor) }
\end{aligned}
$$

\section{Hasil dan Pembahasan}

\section{Pengelolaan Kualitas Air}

\section{Filterisasi dan Treatment Air}

Kebersihan dan tingkat sterilisasi harus diperhatikan, untuk menghindari dari berbagai kemungkinan serangan penyakit yang bisa berdampak tidak baik pada biota peliharaan. Sebelum masuk ke dalam bak penampungan (tandon) terlebih dahulu dilakukan filterisasi air media menggunakan filter bag untuk mengantisipasi kotoran-kotoran dan lumpur yang terbawa dari sumber mata air bor dan perlakuan air media pemeliharaan 
merupakan salah satu aplikasi pengelolaan kualitas air yang sangat berperan dalam meningkatkan nilai parameter kualitas air.

Tujuan treatment air adalah untuk mensterilisasi mikro organisme yang berbahaya serta untuk menjernihkan air media pemeliharaan. Proses treatmen menggunakan kaporit 10 ppm, setelah pemberian kaporit tersebut, air diaerasi selama 24 jam kemudian dinetralkan menggunakan tiosulfat $1 / 2$ dari jumlah kaporit yang diberikan atau 5 ppm. Setelah air tersebut sudah dinyatakan netral, maka air tersebut siap untuk didistribusikan ke bak larva atau bak pemeliharaan.

\section{Penggunaan Aerator Venturi}

Mesin Venturi termasuk salah satu faktor produksi yang berperan dalam menjaga kandungan oksigen dalam air bak pemeliharaan dalam penelitian ini. Kebutuhan oksigen dalam proses pemeliharaan biota laut semakin meningkat seiring dengan umur biota yang dipelihara. Maka diperlukan suatu sistem dalam pengkayaan $\mathrm{O}^{2}$ yaitu mesin aerator venturi alat tersebut dipasang pada saat udang berumur dua minggu.

Kadar Oksigen terlarut (DO) adalah jumlah oksigen yang tersedia dalam suatu badan air. Tingkat kelangsungan hidup udang sangat dipengaruhi oleh kandungan oksigen terlarut dalam air, dengan tingkat minimum sebesar $3 \mathrm{mg} / \mathrm{l}$ dan untuk pertumbuhan yang ideal berada pada kisaran 4-7 mg/l. Air budidaya dengan kandungan oksigen terlarut pada level $3 \mathrm{mg} / \mathrm{l}$, dapat mempengaruhi pertumbuhan udang walaupun tidak mempelihatkan gejala abnormal (Rahma et al., 2014).

\section{Penggunaan Probiotik}

Menurut Masithah et al., (2016), bahwa probiotik adalah mikroorganisme yang memiliki kemampuan mendukung pertumbuhan dan produktifitas udang. Probiotik berfungsi untuk meningkatkan nilai kualitas air karena dapat mengurai senyawa-senyawa sisa metabolisme biota dalam air, selain itu juga berfungsi untuk menyeimbangkan mikroorganisme dalam pencernaan udang agar memiliki tingkat serapan yang tinggi.

Probiotik yang digunakan dalam penelitian ini yaitu Bio Bacter dan M4 Perikanan. Pemberian probiotik Bio Bacter dilakukan pada awal pemeliharaan sampai umur 2 minggu sebanyak 0,5 liter $/ \mathrm{m}^{3}$ air, setiap satu minggu sekali, hal ini untuk menjaga daya tahan udang peliharaan. Ketika umur udang lebih dari 2 minggu penggunaan probiotik Bio Bacter diganti dengan probiotik M4 Perikanan yang ditambahkan ke dalam pakan melalui fermentasi dan penambahan langsung ke air media sebanyak $25 \mathrm{ml} / \mathrm{m}^{3}$ air. Penggunaan aplikasi pemberian probiotik M4 Perikanan lebih banyak dibandingkan dengan penggunaan Bio Bacter untuk menjaga kualitas air media, selain itu juga diharapkan dapat memacu pertumbuhan udang lebih cepat. 
http://ojs.stiperkutim.ac.id/index.php/jpt https://doi.org/10.36084/jpt..v9i2.337
Jurnal Pertanian Terpadu 9(2): 162-176, Desember 2021 ISSN 2549-7383 (online) ISSN 2354-7251 (print)

\section{Pergantian Air}

Pergantian air pada penelitian ini dimaksudkan untuk menjaga stabilitas kualitas air untuk mendukung pertumbuhan udang dan meminimalisir mortalitas biota laut yang dipelihara (udang). Pergantian air berguna untuk mengencerkan bahan organik sisa metabolisme dan sisa pakan (Budiardi et al., 2007). Melakukan pergantian air secara teratur juga mampu membantu memasok oksigen terlarut (Fuady et al., 2013). Pergantian air dilakukan sekali seminggu sebanyak 10-20\% dari volume air kolam.

\section{Parameter Kualitas Air}

Parameter kualitas air yang diukur meliputi salinitas derajat keasaman $(\mathrm{pH})$, oksigen terlarut, suhu dan nitrit $\left(\mathrm{NO}_{2}\right)$.

1. Salinitas

Peranan salinitas dalam pertumbuhan udang memegang peranan penting, karena merupakan bagian dari aspek kualitas air yang harus diperhatikan dalam budidaya. Hasil pengukuran salinitas dapat dilihat pada tabel berikut ini:

Tabel 1. Rata-rata hasil pengukuran salinitas pada air media udang windu ( $P$. monodon)

\begin{tabular}{clccc}
\hline Minggu Ke & \multicolumn{1}{c}{$\begin{array}{c}\text { Waktu } \\
\text { pengukuran }\end{array}$} & $\begin{array}{c}\text { Nilai } \\
\text { maksimum } \\
\text { (ppt) }\end{array}$ & $\begin{array}{c}\text { Nilai } \\
\text { minimum } \\
\text { (ppt) }\end{array}$ & $\begin{array}{c}\text { Rataan } \\
\text { (ppm) }\end{array}$ \\
\hline \multirow{4}{*}{ I } & Pagi & 18 & 16 & 17,00 \\
& Siang & 20 & 18 & 19,00 \\
& Sore & 19 & 17 & 18,00 \\
& Malam & 18 & 16 & 17,00 \\
\hline \multirow{4}{*}{ II } & Pagi & 19 & 16 & 17,50 \\
& Siang & 20 & 19 & 19,50 \\
& Sore & 20 & 18 & 19,00 \\
& Malam & 19 & 17 & 18,00 \\
\hline \multirow{4}{*}{ III } & Pagi & 18 & 17 & 17,50 \\
& Siang & 19 & 17 & 18,00 \\
& Sore & 19 & 17 & 18,00 \\
& Malam & 18 & 16 & 17,00 \\
\hline \multirow{2}{*}{ IV } & Pagi & 18 & 15 & 16,50 \\
& Siang & 19 & 16 & 17,50 \\
& Sore & 19 & 16 & 17,50 \\
& Malam & 17 & 15 & 16,00 \\
\hline
\end{tabular}

Salinitas adalah konsentrasi total dari semua ion dalam air. Untuk tumbuhan dan berkembangnya organisme yang dibudidayakan mempunyai toleransi optimal. Menurut Standar Nasional Indonesia (2007), bahwa salinitas yang optimum pada budidaya pembesaran udang windu Paneus monodon (Fabricius, 1798) berkisar antara 15-30 ppt. Pada penelitian ini salinitas yang diperoleh berada pada kisaran 15-20 ppt, hal ini menunjukkan bahwa pada kisaran tersebut biota laut ( $P$. monodon) dapat tumbuh dengan baik. Sesuai pendapat Ratnawati (2008) yang menyatakan bahwa untuk menunjang pertumbuhan pada pembesaran udang windu kisaran salinitas optimal yaitu 15-25 ppt dan pertumbuhan akan lebih cepat pada kisaran 5-10 ppt, tetapi lebih rentan terhadap penyakit. 
Untuk melihat kisaran salinitas secara keseluruhan selama penelitian disajikan pada gambar 1 berikut ini:

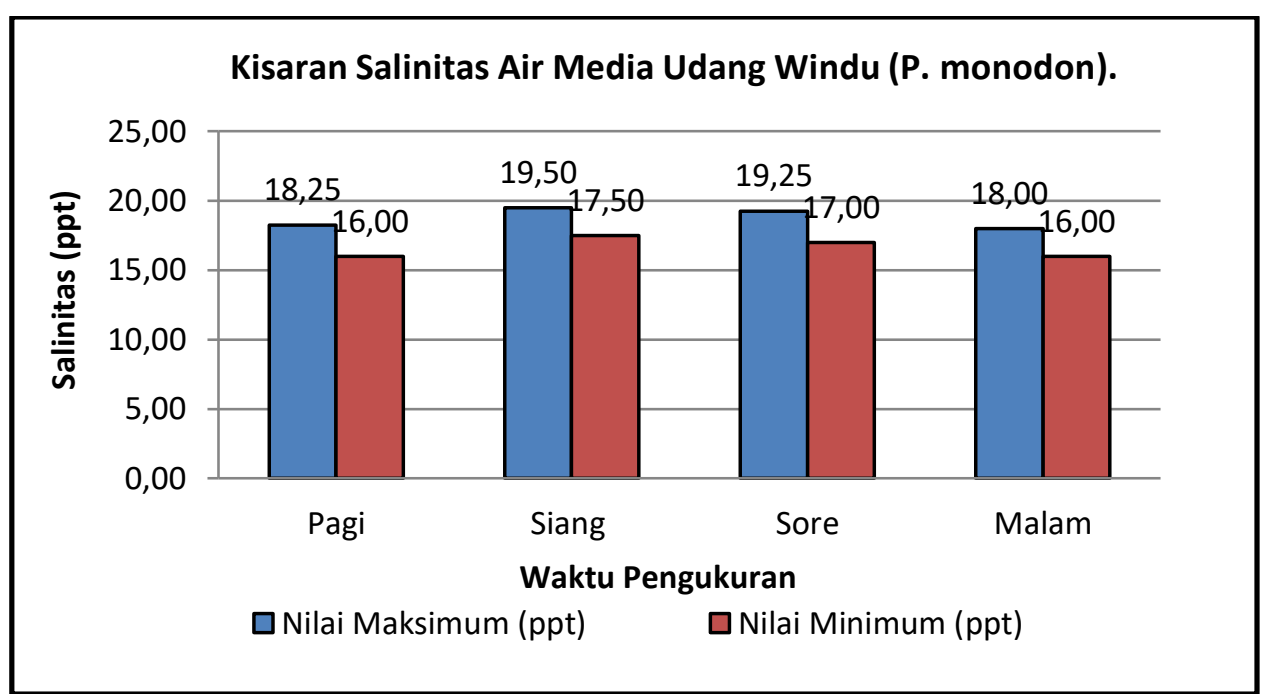

Gambar 1. Grafik kisaran salinitas selama penelitian

Salinitas air sumur bor merupakan satu diantara parameter kualitas air media pemeliharaan pada saat penelitian masih perlu dikontrol atau peningkatan konsentrasi kadar garam untuk biota udang (Panaeus monodon), karena nilai rata-rata salinitas yang diperoleh hanya berada pada kisaran 16,00-19,50 ppt, akan tetapi pada kisaran salinitas yang dihasilkan pada penelitian ini cukup bermanfaat untuk perkembangan udang (Panaeus monodon), sebab menurut Nurhidayah et al., (2012), bahwa untuk kegiatan budidaya udang windu salinitas air media pemeliharaan diatas 30 ppt dinyatakan sangat tinggi dan kurang baik untuk pertumbuhan.

Salinitas yang tinggi berdampak kurang menguntungkan pada pertumbuhan udang, seperti udang akan sulit untuk ganti kulit (molting/kulit cenderung keras) pada saat proses biologis bagi pertumbuhan dan perkembangan, untuk beradaptasi terhadap salinitas yang tinggi udang membutuhkan energi cukup banyak bahkan melebihi dari nutrisi yang diperoleh oleh udang dan dalam kondisi tersebut udang dapat mengalami stress serta rentan terhadap penurunan parameter kualitas air.

\section{2. $\mathrm{pH}$ (Tingkat Keasaman)}

Konsentrasi $\mathrm{pH}$ menentukan kondisis basa dan asam air. Djunaedi et al., (2016), mengatakan bahwa kelangsungan hidup dan pertumbuhan udang dapat juga dipengaruhi oleh tinggi rendahnya nilai $\mathrm{pH}$ air. Hal ini berkaitan dengan proses kecepatan reaksi kimia di dalam air media maupun reaksi biokimia dalam tubuh udang dan mempengaruhi daya racun suatu senyawaan. Kisaran nilai optimum $\mathrm{pH}$ perairan yang sesuai untuk pertumbuhan post larva udang windu adalah antara 6,5 hingga 9,0. 
Rata-rata hasil pengukuran $\mathrm{pH}$, pemanfaatan air sumur bor sebagai media udang Windu (Panaeus monodon), selama penelitian dapat dilihat pada tabel 2 berikut ini:

Tabel 2. Rata-rata hasil pengukuran $\mathrm{pH}$ air media (Panaeus monodon)

\begin{tabular}{|c|c|c|c|c|}
\hline Minggu Ke & Waktu Pengukuran & Nilai maksimum & Nilai minimum & Rataan \\
\hline \multirow{4}{*}{ I } & Pagi & 7,5 & 7,2 & 7,4 \\
\hline & Siang & 8,0 & 7,6 & 7,8 \\
\hline & Sore & 7,7 & 7,4 & 7,6 \\
\hline & Malam & 7,3 & 7,0 & 7,2 \\
\hline \multirow{4}{*}{ II } & Pagi & 7,8 & 7,5 & 7,7 \\
\hline & Siang & 8,2 & 7,7 & 7,9 \\
\hline & Sore & 8,0 & 7,5 & 7,8 \\
\hline & Malam & 7,5 & 7,1 & 7,3 \\
\hline \multirow{4}{*}{ III } & Pagi & 7,7 & 7,2 & 7,5 \\
\hline & Siang & 8,0 & 7,7 & 7,9 \\
\hline & Sore & 8,0 & 7,6 & 7,8 \\
\hline & Malam & 7,4 & 7,0 & 7,2 \\
\hline \multirow{4}{*}{ IV } & Pagi & 7,7 & 7,5 & 7,6 \\
\hline & Siang & 8,2 & 7,9 & 8,1 \\
\hline & Sore & 8,0 & 7,7 & 7,8 \\
\hline & Malam & 7,5 & 7,2 & 7,4 \\
\hline
\end{tabular}

Konsentrasi $\mathrm{pH}$ air pada wadah kolam terpal percobaan dari awal hingga akhir penelitian berada pada kisaran 7,1 sampai 8,2. Dari hasil tersebut menunjukkan bahwa kisaran ini masih layak untuk kehidupan biota laut udang windu (Panaeus monodon) sesuai pendapat Utojo \& Mustafa (2016) bahwa pH yang baik untuk pertumbuhan udang windu berkisar antara 7-8,5.

Meningkatnya sisa-sisa pakan yang tidak terakumulasi oleh biota yang dipelihara dan kegiatan fotosintesis fitoplankton dalam air, dapat memicu $\mathrm{pH}$ air media pemeliharaan udang dapat berubah menjadi asam karena penyerapan $\mathrm{CO}^{2}$ dalam air, oleh sebab itu pada sore hari $\mathrm{pH}$ air akan lebih tinggi daripada pagi hari. Hal ini sesuai dengan pendapat Boyd et al., (2018), bahwa pada siang hari nilai pH akan meningkat akibat terjadinya fotosintesa maka konsentrasi $\mathrm{CO}^{2}$ menurun dan pada malam hari $\mathrm{pH}$ air menurun karena seluruh organisme dalam air melepaskan $\mathrm{CO}^{2}$ dari hasil respirasi. Akan tetapi, nilai $\mathrm{pH}$ air payau sangat konstan sehingga jarang turun mencapai dibawah 6,5 atau meningkat hingga mencapai nilai 9 , sehingga efek buruk pada kultivan jarang terjadi 


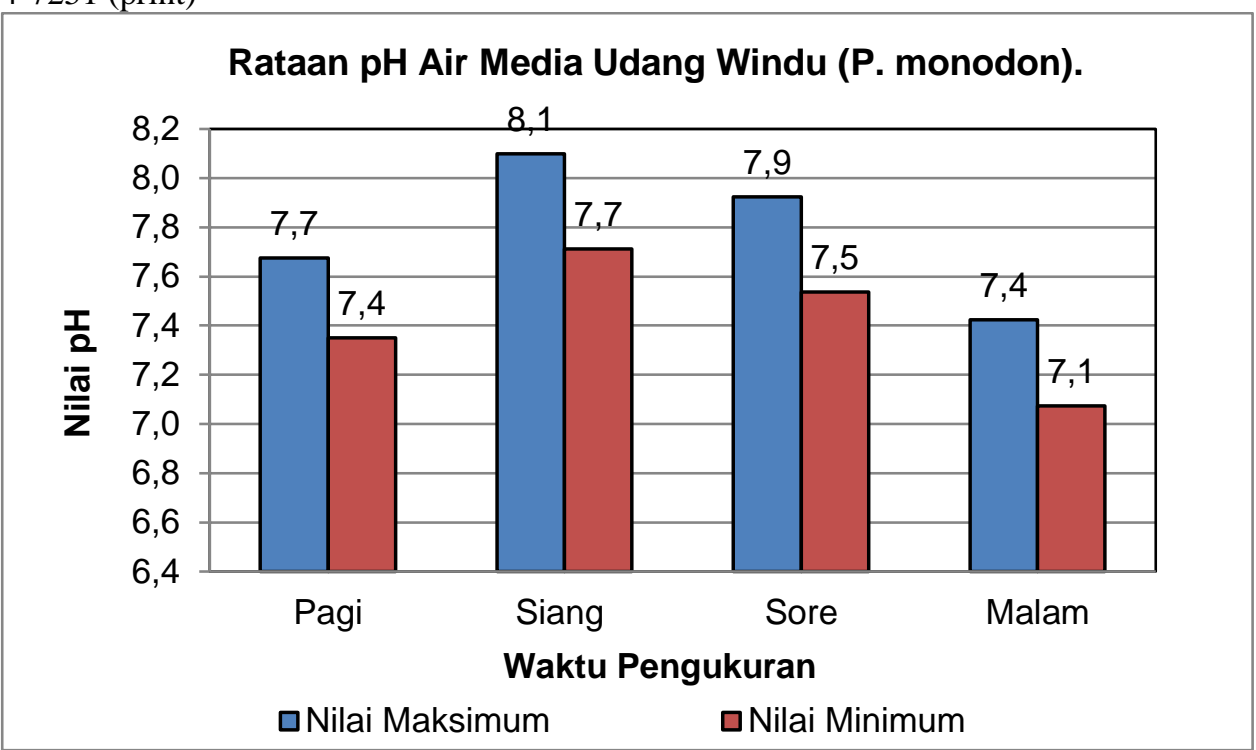

Gambar 2. Grafik kisaran rata-rata nilai pH selama penelitian

Fluktuasi $\mathrm{pH}$ pada air media selama pemeliharaan terlihat setiap hari dan pada waktu pengukuran. Kenaikan $\mathrm{pH}$ ini diduga terjadi karena selain dari sisa pakan juga disebabkan oleh pengelolaan air yang yang baik, maka dalam penelitian ini dilakukan penggunaan probiotik dan pergantian air yang terkontrol.

Penurunan $\mathrm{pH}$ juga dapat diakibatkan oleh faktor lain, misalnya adanya masukan air hujan ke dalam kolam pemeliharaan. Walaupun penurunannya tidak terjadi secara spontan, akan tetapi untuk mengatasi hal tersebut, maka penelitian ini mengantisipasi dengan pengatapan kolam pemeliharaan, sehingga tempat penelitian bersifat semi tertutup sehingga terjadi kestabilan air media dan dapat mengurangi fluktuasi pada $\mathrm{pH}$ harian.

3. Oksigen Terlarut (DO)

Konsentrasi oksigen terlarut (Dissolved Oxygen/DO) merupakan salah satu faktor penting yang perlu diperhatikan sebagai pendukung perkembangan dan pertumbuhan biota, karena organisme dalam perairan memanfaatkan oksigen sebagai bahan proses respirasi dan oksigen dimanfaatkan mikro organisme menguraikan zat organik menjadi anorganik (Patty, 2018). Organiseme perairan sangat membutuhkan oksigen untuk pernafasan dan metabolisme. Penurunan tingkat kelulushidupan udang dan biota air, sangat tergantung cukup atau tidaknya kebutuhan oksigen dalam media budidaya.

Dari hasil pengukuran konsentrasi oksigen terlarut memperlihatkan bahwa tingkat oksigen terlarut pada siang sampai sore hari masih berada dalam kisaran yang dapat ditoleransi untuk kehidupan biota laut (Panaeus monodon) yaitu antara 4,2-6,2 mg/l, hal ini sesuai dengan pendapat Banun et al., (2012) menyatakan bahwa oksigen terlarut dalam air berperan sebagai pendekomposisi limbah organik dalam badan air dan oksigen optimum untuk budidaya udang ialah 3-6 mg/L. Hal yang sama pula yang diutarakan oleh Fuady et al., (2013), bahwa kadar oksigen terlarut yang baik untuk pertumbuhan udang pada tambak 
intensif berkisar antara 3,9-7,8 mg/l, namun angka tersebut fluktuatif, yang artinya tidak signifikan terhadap kelangsungan hidup biota (Panaeus monodon), atau secara garis besar oksigen terlarut pada penelitian ini masih dalam kisaran yang layak untuk udang windu (Panaeus monodon). Hasil pengukuran rata-rata oksigen terlarut, pada penelitian pemanfaatan air sumur bor sebagai media udang windu (Panaeus monodon), dapat dilihat pada tabel 3 berikut ini:

Tabel 3. Rata-rata hasil pengukuran oksigen terlarut air media (Panaeus monodon)

\begin{tabular}{clccc}
\hline \multirow{2}{*}{ Minggu Ke } & Waktu Pengukuran & \multicolumn{3}{c}{ Nilai } \\
\cline { 3 - 5 } & & $\begin{array}{c}\text { Maksimum } \\
(\mathbf{m g} / \mathbf{l})\end{array}$ & Minimum (mg/l) & $\begin{array}{c}\text { Rataan } \\
(\mathbf{m g} / \mathbf{l})\end{array}$ \\
\hline \multirow{4}{*}{ I } & Pagi & 5,4 & 4,0 & 4,7 \\
& Siang & 6,8 & 5,5 & 6,2 \\
& Sore & 6,0 & 5,2 & 5,6 \\
& Malam & 4,4 & 4,1 & 4,3 \\
\hline \multirow{4}{*}{ II } & Pagi & 5,0 & 4,2 & 4,6 \\
& Siang & 6,5 & 5,3 & 5,9 \\
& Sore & 6,0 & 5,2 & 5,6 \\
& Malam & 4,2 & 4,0 & 4,1 \\
\hline \multirow{4}{*}{ III } & Pagi & 5,0 & 4,2 & 4,6 \\
& Siang & 6,0 & 5,2 & 5,6 \\
& Sore & 5,7 & 4,5 & 5,1 \\
& Malam & 3,9 & 3,5 & 3,7 \\
\hline \multirow{4}{*}{ IV } & Pagi & 4,9 & 4,0 & 4,5 \\
& Siang & 5,7 & 4,5 & 5,1 \\
& Sore & 5,5 & 4,3 & 4,9 \\
& Malam & 3,9 & 3,5 & 3,7 \\
\hline
\end{tabular}

Fluktuasi rata-rata pengukuran DO selama penelitian, tersaji pada gambar grafik berikut ini:

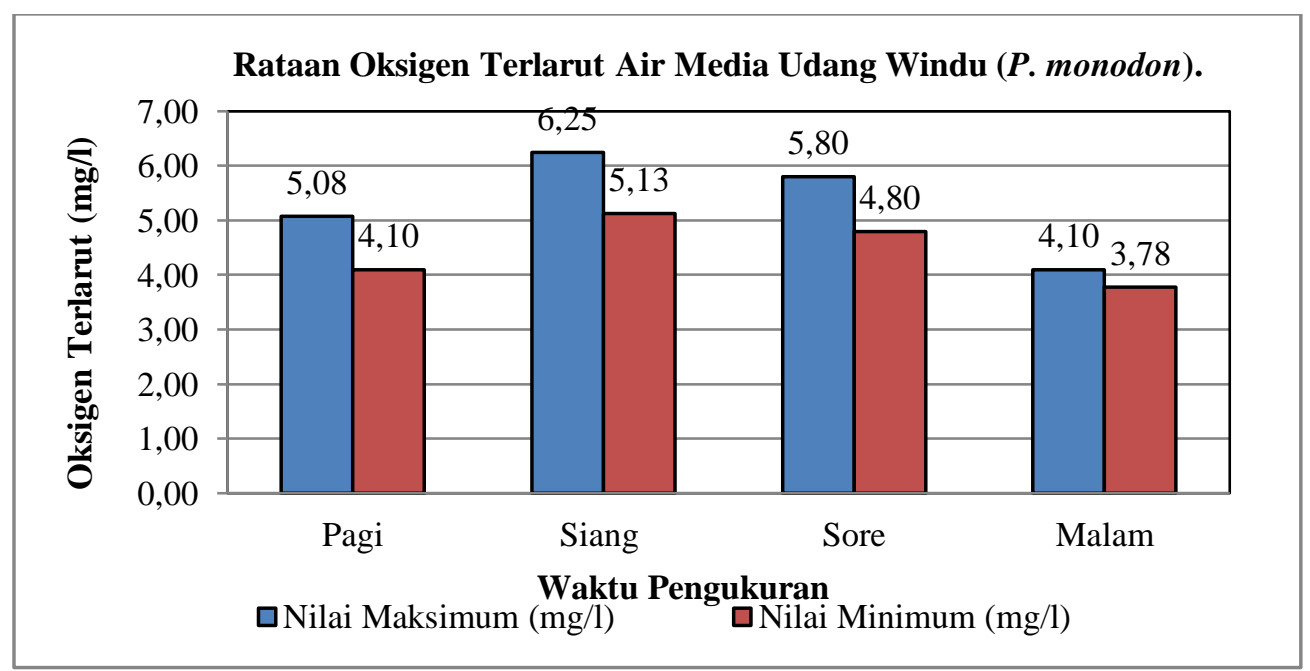

Gambar 3. Grafik kisaran rata-rata oksigen terlarut selama penelitian

Konsentrasi oksigen terlarut (DO) dalam air media pemeliharaan berfluktuasi dalam 24 jam selama sehari semalam. Pada waktu subuh (dini hari) terjadi konsentrasi DO yang sangat rendah dan akan meningkat pada siang hari kemudian akan kembali turun pada malam hari. Konsentrasi oksigen tersebut akan menurun pada malam hari akibat adanya 
ISSN 2354-7251 (print)

proses respirasi dari biota perairan hingga mencapai titik minimum pada pagi hari menjelang fajar. Menurut Effendi (2003), Oksigen terlarut (DO) dalam perairan tergantung pada pencampuran (mixing) dan pergerakan (turbulence) massa air, aktivitas fotosintesis, respirasi, dan limbah (effluent) yang masuk ke dalam air maka dari itu DO akan bersifat fluktuatif secara harian (diurnal) dan musim.

4. Suhu

Hasil pengukuran rata-rata suhu harian pada saat penelitian dapat dilihat pada tabel 4 berikut ini:

Tabel 4. Rata-rata hasil pengukuran suhu air media (Panaeus monodon)

\begin{tabular}{clccc}
\hline \multirow{2}{*}{ Minggu ke } & Waktu pengukuran & \multicolumn{3}{c}{ Nilai } \\
\cline { 3 - 5 } & & Maksimum $\left({ }^{\circ} \mathbf{C}\right)$ & Minimum $\left({ }^{\circ} \mathbf{C}\right)$ & Rataan $\left({ }^{\circ} \mathbf{C}\right)$ \\
\hline \multirow{4}{*}{ I } & Pagi & 27,3 & 26,5 & 26,9 \\
& Siang & 30,0 & 28,7 & 29,4 \\
& Sore & 29,5 & 27,9 & 28,7 \\
& Malam & 27,7 & 26,5 & 27,1 \\
\hline \multirow{4}{*}{ II } & Pagi & 28,0 & 27,1 & 27,6 \\
& Siang & 30,4 & 29,0 & 29,7 \\
& Sore & 29,0 & 27,8 & 28,4 \\
& Malam & 27,9 & 26,7 & 27,3 \\
\hline \multirow{4}{*}{ III } & Pagi & 27,6 & 26,5 & 27,1 \\
& Siang & 29,0 & 27,9 & 28,5 \\
& Sore & 28,5 & 27,0 & 27,8 \\
& Malam & 27,7 & 26,7 & 27,2 \\
\hline \multirow{4}{*}{ IV } & Pagi & 27,8 & 26,5 & 27,2 \\
& Siang & 29,3 & 27,7 & 28,5 \\
& Sore & 28,0 & 27,3 & 27,7 \\
& Malam & 27,5 & 26,5 & 27,0 \\
\hline
\end{tabular}

Suhu dapat berpengaruh terhadap pertumbuhan dan kelangsungan hidup udang. Berbagai jenis udang membutuhkan suhu lingkungan optimal tertentu untuk masing-masing spesiesnya. Suhu pada air media pemeliharaan udang umumnya sangat berperan dalam keterkaitan dengan nafsu makan dan proses metabolisme udang.

Dari tabel hasil pengukuran suhu harian diatas, suhu tertinggi diperoleh pada waktu siang hari sebesar $30,4^{\circ} \mathrm{C}$ dan suhu terendah pada waktu pagi dan malam hari sebesar $26,5^{\circ} \mathrm{C}$ hasil tersebut masih merupakan kisaran suhu yang dapat ditolerir untuk kehidupan biota peliharaan (Panaeus monodon). Kisaran tersebut menurut Widanarni et al., (2010) menyatakan bahwa udang windu yang dapat bertahan hidup pada kisaran suhu $22-31^{\circ} \mathrm{C}$, kisaran tersebut masih dapat ditolerir karena udang windu memiliki sifat eurythermal. Untuk melihat rata-rata kisaran suhu selama penelitian, tersaji pada gambar grafik berikut ini: 


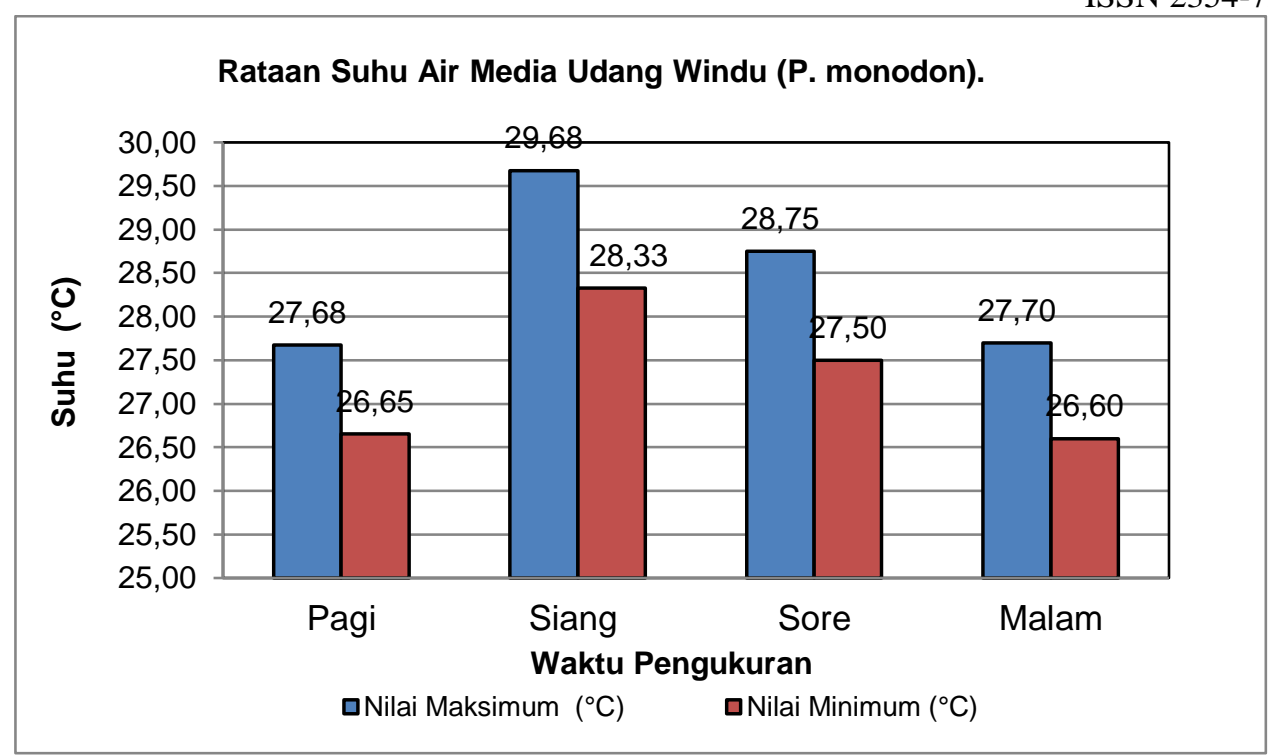

Gambar 4. Grafik kisaran rata-rata suhu selama penelitian

Rata-rata konsentrasi suhu harian air media selama penelitian berkisar 26,60$29,68^{\circ} \mathrm{C}$, rata-rata suhu tertinggi diperoleh pada waktu pengamatan siang hari, diduga pada waktu siang hari terjadi intensitas penguapan air media yang tinggi, dan rata-rata konsentrasi suhu terendah diperoleh pada waktu pengamatan malam hari. Kisaran ratarata suhu tersebut masih layak untuk biota laut jenis udang. Menurut Usman \& Rochmady (2017), bahwa suhu air media budidaya pada kisaran $29-30^{\circ} \mathrm{C}$ baik untuk pertumbuhan dan kehidupan udang. Akan tetapi pada kisaran suhu $18^{\circ} \mathrm{C}$ dan $36^{\circ} \mathrm{C}$ udang masih dapat hidup, walapun udang sudah tidak aktif. Untuk pertumbuhan yang optimal udang berada pada kisaran suhu $25-32^{\circ} \mathrm{C}$.

Kondisi fluktuasi suhu yang berubah dalam jangka waktu lama, perlu dihindari untuk menjaga kelangsungan hidup biota peliharaan, sebab dapat berakibat fatal apabila pengelolaan kualitas airnya kurang memadai. Menurut Horne \& Goldman (1994), bahwa terjadi penurunan biomassa maupun keanekaragaman jenis ikan ketika suhu air lebih besar dari $28^{\circ} \mathrm{C}$, sedangkan jika suhu air media pemeliharaan turun hingga di bawah $25^{\circ} \mathrm{C}$, daya cerna udang windu terhadap makanan yang dikonsumsi berkurang. Sebaliknya, jika suhu naik hingga lebih dari $30^{\circ} \mathrm{C}$, udang windu akan mengalami stress karena kebutuhan oksigen semakin tinggi, karena itu, harus dihindari perubahan suhu secara mendadak karena akan berpengaruh langsung terhadap kehidupan udang (Amri, 2003).

\section{Teknik Pergantian dan Volume Air yang Terpakai}

Selama pemeliharaan biota (Panaeus monodon) pada wadah kolam terpal selain pergantian air juga perlu dilakukan penambahan air. Hal ini terjadi akibat terjadinya penguapan dan pembuangan air limbah pada saat penyiponan. Pergantian air dilakukan setiap seminggu sekali sebanyak 10-20 \% dan untuk mempertahankan ketinggian air seperti semula maka setiap tiga hari sekali dilakukan penambahan air antara $2-5 \mathrm{~cm}$. 
Untuk pergantian dan penambahan air media maka terlebih dahulu dilakukan disterilisasi pada kolam tandom menggunakan kaporit sebanyak 10 ppm, kemudian diaerasi selama 24 jam, untuk menghilangkan bau dam menjernihkan di lakukan pemberian tiosulfat sebanyak 5 ppm. Selanjutnya pengendapan dilakukan selama 3 hari dan air sudah siap didistribusikan ke dalam kolam pemeliharaan. Penggunaan probiotik dilakukan sekali seminggu untuk mempertahankan kualitas air agar dapat mengantisipasi meningkatnya amoniak dan $\mathrm{H}_{2} \mathrm{~S}$ sebanyak 10-15 ppm, karena dalam penelitian ini bertujuan untuk mengetahui kelayakan air sumur bor menjadi media budidaya udang pada pada kolam terpal, maka perlu dilakukan perhitungan volume air yang terpakai selama penelitian.

Perhitungan volume air yang masuk ke dalam kolam pemeliharaan dimaksudkan untuk mengetahui kemampuan sumber air yang ada dalam sumur bor dan kebutuhan kolam yang akan diisi. Hasil penelitian tentang kebutuhan air kolam pemeliharaan dapat dilihat pada tabel 5:

Tabel 5. Kemampuan sumber air dan kebutuhan air kolam pemeliharaan

\begin{tabular}{|c|c|c|c|c|c|c|c|c|c|c|}
\hline \multirow[b]{2}{*}{ Kolam } & \multirow{2}{*}{$\begin{array}{l}\text { Sumber } \\
\text { air }\end{array}$} & \multirow{2}{*}{$\begin{array}{l}\text { Kemampuan } \\
\text { sumber air }\end{array}$} & \multicolumn{8}{|c|}{ Volume air $\mathbf{M}^{3}$ (kubik) } \\
\hline & & & \multicolumn{6}{|c|}{ Kebutuhan kolam } & \multicolumn{2}{|c|}{$\begin{array}{c}\text { Kemampuan } \\
\text { pompa }\end{array}$} \\
\hline $\begin{array}{l}\text { Penampungan } \\
\text { (Tandom) }\end{array}$ & $\begin{array}{c}\text { Sumur } \\
\text { bor }\end{array}$ & 24 jam & 6 kali & $x$ & 8,000 & $=$ & 48,000 & $\mathrm{M}^{3}$ & 48,000 & $\mathrm{M}^{3}$ \\
\hline $\begin{array}{l}\text { Pemeliharaan I } \\
\text { (Budidaya) }\end{array}$ & $\begin{array}{l}\text { Sumur } \\
\text { bor }\end{array}$ & $24 \mathrm{jam}$ & $\begin{array}{ll}1 & \text { kali } \\
6 & \text { Ganti air }\end{array}$ & $\begin{array}{l}x \\
x\end{array}$ & $\begin{array}{l}4,416 \\
0,883\end{array}$ & $\begin{array}{l}= \\
=\end{array}$ & $\begin{array}{l}4,416 \\
5,299\end{array}$ & $\begin{array}{l}M^{3} \\
M^{3}\end{array}$ & $\begin{array}{l}4,416 \\
5,299\end{array}$ & $\begin{array}{l}M^{3} \\
M^{3}\end{array}$ \\
\hline $\begin{array}{c}\text { Pemeliharaan II } \\
\text { (Budidaya) }\end{array}$ & $\begin{array}{c}\text { Sumur } \\
\text { bor }\end{array}$ & $24 \mathrm{jam}$ & $\begin{array}{ll}1 & \text { kali } \\
6 & \text { Ganti air }\end{array}$ & $\begin{array}{l}x \\
x\end{array}$ & $\begin{array}{l}4,416 \\
0,883\end{array}$ & $\begin{array}{l}= \\
=\end{array}$ & $\begin{array}{l}4,416 \\
5,299 \\
\end{array}$ & $\begin{array}{l}\mathrm{M}^{3} \\
\mathrm{M}^{3}\end{array}$ & $\begin{array}{l}4,416 \\
5,299\end{array}$ & $\begin{array}{l}M^{3} \\
M^{3}\end{array}$ \\
\hline
\end{tabular}

Menurut Lawaputri (2011), bahwa pengelolaan air adalah penambahan dan sirkulasi air dalam kolam budidaya perlu dilakukan karena terjadinya tingkat penguapan yang tinggi dan resapan air yang keluar dari kolam, air yang dijadikan sebagai tambahan adalah air laut yang dipompa dan disaring masuk ke dalam kolam penampungan diendapkan untuk sterilisasi yang disebut tandom.

\section{Tingkat Kelangsungan Hidup atau Survival Rate (SR)}

Tingkat kelangsungan hidup biota laut (udang windu) yang diperoleh selama penelitian hanya sebesar $10 \%$, yaitu dari padat penebaran ke dua kolam pemeliharaan dengan jumlah keseluruhan sebanyak 10.000 ekor benur, diperoleh hasil akhir sebanyak 1000 ekor. Hal ini untuk pengujian kelayakan hidup biota laut dengan memanfaatkan air sumur bor yang ada di lingkuangan area STIPER dapat dikatakan berhasil, walaupun dengan Surfaifal Rate (SR) yang rendah.

Dari hasil pengamatan kualitas air selama penelitian, titik yang lemah hanya pada parameter konsentarsi oksigen terlarut (DO). Untuk mengantisifasi kekurangan ini masih dapat dilakukan dengan penambahan aerasi, sehingga oksigen dalam wadah pemeliharaan dapat terpenuhi, rendahnya konsentarsi oksigen terlarut dalam wadah 
percobaan, diduga akibat seringnya terjadi pemadaman listrik, sehingga mesin blower dan venturi sering tidak berfungsi dengan baik.

Tingkat kelangsungan hidup atau Survival Rate yang rendah pada penelitian ini juga dipengaruhi oleh tingkat kepadatan pada awal penebaran, hal ini sejalan dengan pendapat Hendradjat \& Mangampa (2016), bahwa kepadatan biota merupakan salah satu faktor yang menentukan tingkat kelangsungan dalam usaha budidaya udang windu, kemudian dipertegas lagi oleh Kholifah et al., (2008) menyatakan bahwa terjadinya variasi kematian benih dalam media budidaya udang disebabkan karena padatnya benih udang yang ditebar, sehingga timbul sifat kanibal pada udang.

\section{Kesimpulan}

Berdasarkan hasil pengamatan dan evaluasi data sifat fisik, kimiawi dan biologi air sumur bor yang terdapat di area STIPER Kutai Timur, dapat disimpulkan bahwa secara sifat fisik dan kimia air sumur bor yang ada di area kampus STIPER Kutai Timur, dalam konsentrasi yang layak untuk digunakan sebagai media budidaya udang windu (Panaeus monodon).

\section{Daftar Pustaka}

Amri, K. (2003). Budidaya Udang Windu Secara Intensif. Agromedia Pustaka.

Athirah, A., Hasnawi, \& Paena, M. (2014). Faktor Pengelolaan yang Memengaruhi Produktivitas Tambak Di Kabupaten Demak Provinsi Jawa Tengah. Prosiding Forum Inovasi Teknologi Akuakultur, 485-491.

Banun, S., Arthana, W., \& Suarna, W. (2012). Kajian Ekologis Pengelolaan Tambak Udang Di Dusun Dangin Marga Desa Delodbrawah Kecamatan Mendoyo Kabupaten Jembrana Bali. Ecotrophic: Journal of Environmental Science, 3(1), 10-15.

Boyd, C. E., Torrans, E. L., \& Tucker, C. S. (2018). Dissolved Oxygen and Aeration in Ictalurid Catfish Aquaculture. Journal of the World Aquaculture Society, 49(1), 7-70. https://doi.org/10.1111/jwas.12469

Badan Pusat Statistik Kabupaten Kutai Timur. (2018). Kabupaten Kutai Timur Dalam Angka. BPS Kabupaten Kutai Timur.

Budiardi, T., Widyaya, I., \& Wahjuningrum, D. (2007). Hubungan Komunitas Fitoplankton dengan Produktivitas Udang Vanamei F (Litopenaeus vannamei) di Tambak Biocrete. Jurnal Akuakultur Indonesia, 6(2), 119-125. http://journal.ipb.ac.id/index.php/jai\%5Cnhttp://jurnalakuakulturindonesia.ipb.ac.id

Dasanto, B. D., Sulistiyanti, Anria, A., \& Boer, R. (2020). Dampak Perubahan Iklim Terhadap Kenaikan Muka Air Laut Di Wilayah Pesisir Pangandaran. Risalah Kebijakan Pertanian Dan Lingkungan Rumusan Kajian Strategis Bidang Pertanian Dan Lingkungan, 7(2), 82-94. https://doi.org/10.29244/jkebijakan.v7i2.28039

Djunaedi, A., Susilo, H., \& Sunaryo. (2016). Kualitas Air Media Pemeliharaan Benih Udang Windu (Penaeus monodon Fabricius) dengan Sistem Budidaya yang Berbeda. Jurnal Kelautan Tropis, 19(2), 171-178. https://doi.org/10.14710/jkt.v19i2.846

Effendi, H. (2003). Telaah Kualitas Air. Kanisius. 
Erawan, M. T. F., Mustafa, A., Oetama, D., Purnama, M. F., Pratikino, A. G., \& Wahidin, L. O. (2021). Studi Kesesuaian Tambak Udang Windu (Penaeus Monodon) di Desa Oensuli Kabupaten Muna Sulawesi Tenggara. Jurnal IImu Dan Teknologi Kelautan Tropis, 13(1), 141-150. https://doi.org/https://doi.org/10.29244/jitkt.v13i1.28511

Fuady, M. F., Supardjo, M. N., \& Haeruddin. (2013). Pengaruh Pengelolaan Kualitas Air terhadap Tingkat Kelulushidupan dan Laju Pertumbuhan Udang Vaname (Litopenaeus vannamei) Di Pt. Indokor Bangun Desa, Yogyakarta. Management of Aquatic Resources Journal (MAQUARES), 2(4), 155-162. https://doi.org/10.14710/marj.v2i4.4279

Haliman, R. W., \& Adijaya, D. S. (2006). Udang Vannamei. Penebar Swadaya.

Hendradjat, E. A., \& Mangampa, M. (2016). Pertumbuhan dan Sintasan Udang Vannamei Pola Tradisional Plus Dengan Kepadatan Berbeda. Jurnal Riset Akuakultur, 2(2), 149-156. https://doi.org/http://dx.doi.org/10.15578/jra.2.2.2007.149-156

Hendrajat, E. A., Ratnawati, E., \& Mustafa, A. (2018). Determination of Effect of Soil and Water Quality To Total Production of Polyculture White Shrimp and Milk Fish Ponds in Lamongan Regency, East Java Province Through Path Analysis Application. Jurnal IImu Dan Teknologi Kelautan Tropis, 10(1), 179-195. https://doi.org/http://dx.doi.org/10.29244/jitkt.v10i1.21675

Horne, A. J., \& Goldman, C. R. (1994). Limnolgy (2nd ed). McGraw-Hill.

Kholifah, U., Trisyani, N., \& Yuniar, I. (2008). Pengaruh Padat Tebar yang Berbeda terhadap Kelangsungan Hidup dan Pertumbuhan pada Polikultur Udang Windu (Penaeus Monodon Fab) dan Ikan Bandeng (Chanos Chanos) pada Hapa di Tambak Brebes - Jawa Tengah. Neptunus, 14(2), 152-158. http://dspace.hangtuah.ac.id/xmlui/bitstream/handle/dx/297/Neptunus januari 2008.pdf?sequence $=1$ \&isAllowed $=y$

Lawaputri, A. T. (2011). Analisis Kelayakan Finansial Usaha udang Vannamei (Litopaneaus vannamei) pada Tambak Intensif di Kabupaten Takalar (Studi Kasus Usaha tambak udang Kurnia Subur). Skripsi Fakultas IImu Kelautan dan Perikanan. Universitas Hasanuddin Kampus Tamalanrea, Makassar.

Masithah, E. D., Octaviana, Y. D., \& Manan, A. (2016). Pengaruh Perbedaan Probiotik Komersial Terhadap Rasio C:N Dan N:P Media Kultur Bioflok Pada Bak Percobaan. Journal of Aquaculture and Fish Health, 5(3), 118-125. https://doi.org/10.20473/jafh.v5i3.11333

Nurhidayah, Tompo, A., \& Susianingsih, E. (2012). Pengelolaan Parameter Kualitas Air Di Tambak Budidaya Udang Windu dengan Aplikasi Probiotik, Bakterin dan Herbal. Seminar Nasional Tahunan IX Hasil Penelitian Perikanan Dan Kelautan Tahun 2012, 14 Juli 2012, Manajemen Sumberdaya Perikanan, UGM, Yogyakarta, 1-7.

Patty, S. I. (2018). Oksigen Terlarut dan Apparent Oxygen Utilization di Perairan Selat Lembeh, Sulawesi Utara. Jurnal Ilmiah Platax, 6(1), 54-60. https://doi.org/https://doi.org/10.35800/jip.6.1.2018.17972

Rahma, H. N., Prayitno, S. B., \& Program, A. H. C. H. (2014). Infeksi White Spot Syndrom Virus (Wssv) Pada Udang Windu (Penaeus Monodon Fabr.) yang Dipelihara pada Salinitas Media yang Berbeda. Journal of Aquaculture Management and Technology, 3(3), 25-34.

Ratnawati, E. (2008). Budidaya Udang Windu (Penaeus monodon) Sistem Semi-Intensif Pada Tambak Tanah Sulfat Masam. Media Akuakultur, 3(1), 6-10. https://doi.org/10.15578/ma.3.1.2008.6-10 
Rudiyanto. (2014). Analisis Nilai Redoks Potensial, Bakteri Sulfur, Bahan Organik Dan Konsentrasi Pirit pada Tekstur Tanah Tambak di Kabupaten Kutai Timur. Tesis Program Studi Magister IImu Kehutanan Fakultas Kehutanan. Universitas Mulawarman, Samarinda.

Standar Nasional Indonesia. (2007). SNI 01-6144-2006: Produksi Benih Udang Windu Penaeus monodon (Fabricius, 1798) Kelas Benih Sebar. Badan Standardisasi Nasional.

Syukri, M., \& Ilham, M. (2016). Pengaruh Salinitas Terhadap Sintasan Dan Pertumbuhan Larva Udang Windu ( Penaeus Monodon ). Jurnal Galung Tropika, 5(2), 86-96.

Usman, A., \& Rochmady. (2017). Pertumbuhan dan Kelangsungan Hidup Pasca Larva Udang Windu ( Penaeus monodon Fabr .) Melalui Pemberian Probiotik dengan Dosis Berbeda. Akuatikisle: Jurnal Akuakultur, Pesisir Dan Pulau-Pulau Kecil, 1(1), 19-26. https://doi.org/10.29239/j.akuatikisle.1.1.19-26

Utojo, \& Mustafa, A. (2016). Plankton Community Structure of Traditional and Intensive Brackishwater Ponds in Probolinggo Regency, East Java Province. Jurnal IImu Dan Teknologi Kelautan Tropis, 8(1), 269-288. https://doi.org/10.29244/jitkt.v8i1.13467

Widanarni, Lidaenni, M. A., \& Wahjuningrum, D. (2010). Pengaruh pemberian bakteri probiotik Vibrio SKT-b dengan dosis yang berbeda terhadap kelangsungan hidup dan pertumbuhan larva udang windu ( Penaeus monodon ) Fab. Effects of different doses of skt-b vibrio probiotic bacteria addition on survival and grow. Jurnal Akuakultur Indonesia 9, 9(1), 21-29. https://doi.org/https://doi.org/10.19027/jai.9.21-29 